\title{
Bog noter
}

\section{Af Vibeke Sperling}

Boo, Katherine: Behind the Beautiful Forevers: Life, death, and hope in a Mumbai undercity. Random House. Reprint edition 2014, 288 s., ISBN: 9780812979329.

Pulitzer prisvinder Katherine Boo beskriver effekterne af globale økonomiske og politiske ændringer gennem historier om indiske familier i Annawadi, et kvarter af midlertidige boliger i skyggen af luksushoteller nær Mumbai lufthavn. I takt med øget velstand i Indien ser indbyggerne i Annawadi håb. Teenageren ser "en formue, der ikke kan tælles" i genbrug af affald, som rige smider væk. En kvinde med store ambitioner har kæmpet sig vej til middelklassen. Med lidt held kan hendes smukke datter blive den første kvindelige student. Og selv de fattigste børn som unge Kalu føler, at deres drømme rykker nærmere.

Terror og recession rammer byen og undertrykte spændinger i form af religion, kaster, sex, magt og økonomisk misundelse ryster byen. Bogen er bygget på modig rapportering og bringer læseren tæt på familier, som er svære at glemme.
Brunner, Florence: Putin's Russia: Politics, Economics, and U.S. Interests. Nova Science Pub Inc 2014, 194 s., ISBN: 9781631172045.

Rusland gjorde visse demokratiske fremskridt i 1990'erne, men de begrænsede fremskridt blev annulleret, efter, at Vladimir Putin kom til magten i 1999-2000. Derefter blev Dumaen (underhuset) domineret af regeringsgodkendte partier, direkte guvernørvalg blev afskaffet og regeringen i Moskva tog ejerskab eller kontrol med større medier og industrier, inklusiv energisektoren. Putins regering viste ringe respekt for love og menneskerettigheder. Dette blev tydeligt i den måde opstande i Nordkaukasus blev undertrykt. Det vakte håb, da Dmitrij Medvedev, Putins mangeårige protege, blev valgt til præsident $\mathrm{i}$ 2008. Medvedev udpegede dog straks Putin til ministerpræsident og Putins politik blev i det store hele fortsat. Bogen bringer gode analyser af politiske og økonomiske forhold i Putins Rusland. Ligeledes belyses de sikkerhedspolitiske implikationer og USA's interesse i den russiske udvikling. 
Carter, Ralph G.: Essentials of U.S. Foreign Policy Making Pearson 2014, 304 s., ISBN: 9780133815016.

Bogen identificerer de forskellige grupper og individer, der skaber amerikansk udenrigspolitik og hvordan teorier som realisme, idealisme og konstruktivisme former deres handlinger efter $-9 / 11$.

Feifer, Gregory: Russians: The People behind the Power. Twelve 2014, 384 s., ISBN: 9781455509645.

På baggrund af mange års journalistisk arbejde i Rusland analyserer Feifer, at meget, som for udenforstående synes uforklarligt ved landet, ser helt logisk ud indefra. Han gør det klart, hvorfor præsident Vladimir Putin forbliver populær i Rusland, selv om kløften øges mellem de superrige og det store fattige flertal.

På rejser igennem Rusland har Feifer haft hundredvis af intime samtaler med russere om alt fra sex, storpolitik og vodka. Fra de enormt rige oligarker til ældre babusjkaer, der tigger i Moskvas gader, fortæller forfatteren historien om et samfund, der er sprængfyldt med vitalitet og med en ledelse, der er bundet af traditioner. Feifer viser et billede af et land, der ofte er på randen af sammenbrud trods den autoritære magtudøvelse.

Bogen er et portræt af et land fyldt med ekstremer. Landet er præget af et nådesløst klima og ødelæggende korruption, men har alligevel frembragt noget af verdens største kunst og nogle af de mest bemærkelsesværdige videnskabelige fremskridt.

Gall, Carlotta: The Wrong Enemy: America in Afghanistan, 2001-2014. Houghton Mifflin Harcourt 2014, 352 s., ISBN: 9780544046696.

Journalisten Carlotta Gall har rapporteret intensivt fra Afghanistan og Pakistan siden USA's invasion af Afghanistan i kølvandet på 9/11. Gall ved, hvor meget det har kostet det afghanske folk og hvor meget af skaden, der kan spores til Pakistan. Nu, hvor amerikanske tropper trækker sig ud, er det ifølge forfatteren på høje tid at fortælle den sande historie om, hvordan vi har udkæmpet den forkerte krig i det forkerte land.

Gall forbinder personlige fortællinger om slag og forræderi med portrætter af almindelige afghanere under mere end et årtis krigsrædsler. Hun bringer troværdige beviser for, at Pakistan ernærede Taliban og beskyttede Osama bin Laden.

Glenthøj, Rasmus: 1864. Sønner af de slagne. Gads Forlag 2014, 576 s., ISBN: 9788712049197.

Der er kommet mange bøger i anledning af 150-året for det danske nederlag i 1864. Glenthøjs bog hæver sig flot i den sammenhæng. Hans fremstilling omhandler den politiske udvikling med inddragelse af kulturelle og mentale faktorer. Dermed bliver det også en bog om dansk identitetsudvikling.

Greenwald, Gleen: No Place to Hide: Edward Snowden, the NSA, and the U.S. Surveillance State. Metropolitan Books 2014, 272 s., ISBN: 9780804173520.

I maj 2013 drog Glen Greenwald til Hong Kong for at møde en anonym kilde, som hævdede, at han havde sensationelle beviser for den amerikanske regerings omfattende spionage. Kilden insisterede på kun at kommunikere igennem strengt krypterede kanaler. Han viste sig at være den 29-årige NSA-agent, Edward Snowden. Snowdens afsløringer af bureauets udbredte og systematiske krænkelser viste sig at være nogle af de mest eksplosive nyheder i nyere historie. De skabte en hidsig debat om national sikkerhed og krænkelse af privatlivets fred. Debatten raser videre, og den amerikanske rege- 
ring overvejer diverse reformer. Historien om Snowden fra insideren Greenwald gør det klart, at vi endnu ikke har set de fulde konsekvenser af Snowdens afsløringer. Bogen er første gang Greenwald stykker alle enderne sammen om sin intensive 11 dages rejse til Hong Kong.

Harding, Luke: The Snowden Files: The Inside Story of the World's Most Wanted Man. Vintage 2014, 352 s., ISBN: 9780804173520.

Det begyndte med en anonym e-mail besked: "Jeg er et seniormedlem af efterretningssamfundet”. Derefter fulgte de mest spektakulære efterretningsafsløringer nogensinde. Edward Snowden rystede verdens ledere og skabte en passioneret offentlig debat om farerne ved overvågning, ikke mindst i form af trusler imod den private sfære.

Den prisvindende The Guardian journalist, Luke Harding, har skrevet en bog, der læses som en hæsblæsende krimi. Han fortæller Snowdens forbløffende historie fra han forlod sin kæreste i Honolulu med hemmeligstemplede filer, til ugerne af hemmelig aktivitet i Hong Kong og hans kamp for asyl i Moskva.

Haas, Richard N.: Foreign Policy Begins at Home: The Case for Putting America's House in Order. Basic Books 2014. 224s., ISBN: 9780465071999.

Præsidenten for Council on Foreign Relations, Richard N. Haas, analyserer USA's største nutidige udfordringer. Et fremadstormende Kina, klimaforandringer, terrorisme, et muligt atomrustet Iran, et turbulent Mellemøsten og et ryggesløst Nordkorea er alt sammen alvorlige udfordringer for USA's nationale sikkerhed. Men udviklingen afhænger i høj grad af, om USA kan tage hånd om sit budgetunderskud og -gæld, landets eroderen- de infrastruktur, tilbagestående skoler og forældede immigrationssystem. Mens der ikke er nogen større rivaliserende magt, som truer USA direkte, vil USA's magtposition i høj grad afhænge af, om USA kan bringe orden i eget hus. Det er de interne amerikanske forhold, der vil være afgørende for, hvor lang tid USA's strategiske forspring vil holde. Med stor indsigt i en fortsat urolig verden tager denne opdaterede version af bogen også USA's Syrienpolitik under behandling. Derudover diskuteres balancen mellem den enkeltes privatliv og kollektiv sikkerhed.

Hartog, Lady: India in Outline. Cambridge University Press 2014, 144 s., ISBN: 978-1107640993.

I denne opdaterede bog, der første gang blev udgivet i 1945, leveres en kort introduktion til Indiens historie, skikke og økonomi. Lady Hartog diskuterer også efterkrigstiden genopbygning af Indien og den rolle, som kvinder af forskellige religioner har spillet i udviklingen. Bogen afspejler i høj grad den britiske historiske opfattelse af Indien.

Irving, Sara: Leila Khaled. Symbolet på Palæstinas Befrielse. Forlaget Solidaritet 2014. $218 \mathrm{~s}$.

29. august 1969 har Leila Khaled fra PFLP smuglet en håndgranat og en pistol gennem sikkerhedskontrollen og om bord på et fly. Hun kaprer sammen med en medsammensvoren flyet og beordrer det til Khaleds hjemby, Haifa. Flyet lander imidlertid i Beirut, hvor de to bliver arresteret. Leila Khaleds karriere som flykaprer synes ovre, da alle kender den smukke flykaprer. En plastikkirurg i Beirut ændrer imidlertid hendes udseende, så hun kan fortsætte og 6. September 1970 stiger hun på et fly i Amsterdam 
sammen med nicaraguaneren Patrick Arguello. Han bliver dræbt og hun arresteret, men sat fri under en fangeudveksling.

I bogen kommer vi tæt på den palæstinensiske kvinder, som kaldes "symbolet på Palæstinas befrielse”. Hun er lige fyldt 70 år, leder Det Palæstinensiske Kvindeforbund og er medlem af Det Palæstinensiske Nationalråd. Bogen beskriver, hvordan hun var med til at sætte palæstinensernes sag på dagsordenen, men også med til at føde en ny stereotyp: Palæstinenserne gik fra at være flygtninge til at blive opfattet som terrorister.

Judah, Ben: Fragile Empire: How Russia Fell In and Out of Love with VladimirPutin. Yale University Press 2014, 400 s., ISBN: 9780300181210.

Journalisten Ben Judah har på rejser gennem Rusland og tidligere sovjetrepublikker foretaget lange interviews med præsident Vladimir Putins venner, fjender, regeringsembedsmænd, erhvervsmagnater, forbrydere og almindelige russiske borgere. Det fremgår af hans forskning og analyser, at der er tale om et skrøbeligt imperium. Trods den officielle russiske propaganda om stabilitet, blev $\mathrm{Pu}$ tins regime i december 2012 pludselig konfronteret med omfattende protester, der viste en anden side af historien. Ifølge Judah bragte putinismen økonomisk vækst til Rusland, men medførte også svagere institutioner og denne modsætning medførte ustabilitet. Forfatteren diskuterer både Putins succeser og uindfriede løfter. Han inddrager betydningen af en ny middelklasse og en ny generation, betydningen af internet, social aktivisme og globalisering for præsidentens truende ledelseskrise.
Kaplan, Robert D.: Asia's Cauldron: The South China Sea and the End of a Stable Pacific. Random House 2014, 256 s., ISBN: 9780812994322.

Med oliereserver på milliarder af tønder, anslået ni hundrede milliarder kubikmeter naturgas og adskillige århundreders stridende territoriale krav, er området ved Det Sydkinesiske Hav en krudttønde af potentielle konflikter. Robert D. Kaplan, som af tidsskriftet Foreign Policy er udpeget til at være blandt verdens 100 fremmeste globale tænkere, giver et indgående blik ind i en skrøbelig region, som i fremtiden vil være domineret af geopolitiske konflikter.

I det seneste årti er verdensmagtens centrum flyttet fra Europa til Asien. Den underrapporterede militære oprustning i området, hvor det vestlige Stillehav møder det Indiske Ocean, betyder ifølge forfatteren, at området efter al sandsynlighed bliver et centrum for geostrategiske stridigheder inden for overskuelig fremtid. Kaplan giver levende snapshots af landene omkring det Sydkinesiske Hav. Han belyser de konflikter, der ulmer i regionen og deres implikationer for global fred og stabilitet. Kaplan analyserer USA's interesser i Asien i lyset af et stadig mere selvhævdende Kina. Han forklarer, hvordan regionens særlige geografi, på den ene side fremmer flådeopbygning, men også arbejder imod aggression. Han drager en slående parallel mellem Kinas bestræbelse for hegemoni i det Sydkinesiske Hav og USA's caribiske imperieeventyr for over et hundrede år siden.

Andersen, Lars Erslev (red.): Terrorisme og trusselsvurderinger. Dansk Institut for Internationale Studier 2014, 172 s., ISBN: 9788776056636.

Er terrortruslen mod Danmark større eller mindre i dag end tidligere, og hvordan vurderer man egentlig en trussel? I bogen ses 
nærmere på nationale, regionale og globale trusselsbilleder. Nuværende og tidligere forskere ved Dansk Institut for Internationale Studier giver i bogen deres bud på, hvordan trusselsbilledet fra radikal islamistisk terror tegner sig, og, hvordan den har udviklet sig de senere år. De forskellige bidrag spænder vidt. Særligt belyses Al Qaeda og relaterede ekstremistiske grupperinger.

Ruthland, Peter: Ukraines's Identity Crisis: Understanding the Protest and Politics. Transitions 2014. File Size 1018 KB, 109 s.

Forventningerne var store op til EU's topmøde i Vilnius 28. November 2013, hvor Ukraine, Moldova, og Georgien skulle underskrive associeringsaftaler med EU. Det blev set som den endelige overvindelse af delingen af Europa med Jalta aftalerne i 1945. Forventningerne blev gjort til skamme 22. November, da Ukraines daværende præsident, Viktor Janukovitj, proklamerede, at han alligevel ikke var parat til at underskrive aftalen med EU.

Ukraine er ifølge bogen trods alle mangler velsignet ved at være mere åbent og pluralistisk end Rusland. Men det har også sin pris. Den pris, som Ukraine betaler for pluralismen, er kronisk ustabilitet og dårlig ledelse. I modsætning til Rusland er den ukrainske stat ikke stærk nok til at undertrykke politiske protester. I 2004 under den såkaldte Orange Revolution var almindelige ukrainere i stand til at gå på gaderne og få annulleret resultatet af valgsvindel, noget som aldrig er sket i Rusland. Men et valg skaber ikke demokrati. Den orange regering, som kom til, skuffede og Viktor Janukovitj blev valgt som præsident i 2010 ved et ret frit valg. Hvordan det går efter Janukovitjs fald kommer denne bog for tidligt til at vurdere, men den giver godt stof til vurdering af det splittede lands identitetskriser.
Schama, Simon: Story of the Jews. Finding the Words 1000 BC - 1492 AD. Eco 2014, 512 s., ISBN: 9780060539184.

I en imponerende flot illustreret kulturhistorie, der har dannet grundlag for PBSog BBC-serien The Story of the Jews, fortæller Schama detaljeret om jødisk liv over tre årtusinder. Fra deres begyndelse som et stammefolk frem til åbningen af Den Nye Verden i 1492 og op til i dag. Han bringer læseren vidt omkring. Fra Indien til Andalusien, fra Cairos basarer til Oxfords gader. Han tager læseren med til andre utrolige steder som eksempelvis et jødisk kongedømme i det sydlige Arabiens bjerge.

Dette er ikke, som titlen fortæller, en bog om jødernes historie, selv om den stort set er kronologisk i sin opbygning og sat ind i en klar geografisk ramme. Det er, som undertitlen viser, en historie hvorom ord næppe slår til. Historien begynder ikke med Abraham eller Moses eller delingen af det Røde Hav, men med en lille gruppe jødiske handlende, der er klemt sammen langt fra venner og familie på en $\varnothing$ nær den første cataract af Nilen, som er i persernes tjeneste. Forfatteren starter således med jøderne tilbage i Egypten, længe efter at Moses førte dem ud. Det er tidligt i det 5. århundere f. kr. Dokumenterne, som jøderne efterlod på øen, som af uforklarlige årsager blev kaldt Elephantine, er de første hårde vidnesbyrd om jødernes dagligliv i antikken.

U.S. Government: 2014 Ukraine and Crimea Crisis: The Crimean Tatars and Their Influence on the Triangle Of Conflict - Russia - Crimea - Ukraine, History of Crimea, Sevastopol, Russian Black Sea Fleet. Kindle Edition 2014, 161 s.

I 1990'erne blev Krim centrum for konflikt mellem Ukraine og Rusland. Dengang drejede det sig om Sortehavsflåden og Krims egen status. Lokale myndigheder benytte- 
de sig af den demografiske situation, hvor ukrainerne var i mindretal. Først krævede Krim-indbyggere autonomi, siden ønskede de at løsrive halvøen fra Ukraine. Krimtatarernes tilbagevenden fra eksil, som Stalin havde tvunget dem i i 1944, uddybede konflikten. Krimtatarerne, der nu udgør omkring 12 procent af halvøens befolkning, udråbte Krim til nationalt territorium for Krimtatarerne med ret til selvstyre som halvøens oprindelige folk, mens de andre folkeslag blev set som kolonimagter. Mens krimtatarernes nationalisme efterhånden fik mindre betydning, voksede flertalsbefolkningen, russernes ønske om at vende tilbage til Rusland stærkt efter Viktor Janukovitjs fald fra Ukraines præsidentpost i februar i år.

U.S. Army College: The Future of USPakistan Relations. CreateSpace Independent Publishing Platform 2014, 52 s. ISBN: 9781497534858.

Analyser af drivkræfterne bag Pakistans udenrigspolitik, og, hvordan USA kan påvirke den for at nå sine mål i regionen. De to mest indflydelsesrige faktorer identificeret $\mathrm{i}$ dette projekt er: Indien, med Kashmir som underelement, og ideologi (islamisk vs. sekulær). Det analyseres, hvordan disse faktorer har indflydelse på Pakistans indre stabilitet, sikkerhed, relationerne til USA samt eksterne faktorer som Indien. Efter analyse af rammevilkårene, ses på mulige løsninger. Dette papir konkluderer, at der ikke kan findes en løsning for Afghanistan eller opnås stabilitet i regionen uden først at tage hensyn til Pakistans interesser og bekymringer.

Vance, Laurence M.: War, Empire, and the Military: Essays on the Follies of War and U.S. Foreign Policy Vance Publications 2014, 528 s., ISBN: 9780982369784.

127 essays om at være i opposition til en "krigsførende stat". Selv om mange af bogens essays omhandler aktuelle udviklinger, er deres emner tidsløse: krig, militarisme, imperiebygning, interventionisme og den krigsførende stat. I kapitel 1 "War and Peace" diskuteres krigens og krigsmageres onder og fordelene ved fred. I kapitel 2 "The Military,' stående hæres og militarismens onder samt et kritisk blik på USA's militær. 3, ”The War in Iraq" om ondskaben ved Irak-krigen. Kapitel 4 "World War II" om den "gode krig", som viste sig ikke så god endda. Kapitel 5 "Other Wars," krigens onder beskrevet ud fra besemte krige: Krim krigen (1854-1856), Den russisk-japanske krig (1904-1905), Første Verdenskrig (1914-1918), Krigen i den Persiske Golf (1990-1991), krigen i Afghanistan (2001- ). Kapitel 6 "The U.S. Global Empire," fremkomsten, omfanget, karakteren og konsekvenserne af det amerikanske militære imperium i det 20. Og 21. århundrede. Kapitel 7 "U.S. Foreign Policy" om hensynsløsheden og fejlerne ved USA's udenrigspolitik.

Woehrel, Steven: Ukraine Current Issues and U.S. Policy. Kindle Edition 2014. File Size 290 Kb, ASIN: Boo51ACV7E.

En bog om optakten til den ukrainske omvæltning, som startede i november 2013. Forfatteren beskriver regimets udemokratiske udvikling og regeringens brug af domstolene til at bekæmpe oppositionsledere. Heraf mest udtalt i sagen imod tidligere ministerpræsident Julia Timosjenko, der blev idømt syv års fængsel på et yderst tvivlsomt grundlag.

Da oprøret brød ud, forsøgte regimet at sikre sig overlevelse med skiftevis indrømmelser og undertrykkelse. De mest alvorlige blodsudgydelse kom 18. Februar, hvor omkring 100 blev dræbt, heraf mange af snigskytter. Bogen gennemgår grundigt både optakten til oprøret, dets forløb og de internationale reaktioner, herunder perspektiver for international hjælp til den ukrainske økonomi, der er på randen af sammenbrud. 